\title{
CD5 Negative
}

National Cancer Institute

\section{Source}

National Cancer Institute. CD5 Negative. NCI Thesaurus. Code C162057.

An indication that CD5 expression has not been detected in a sample. 